\title{
Dario Savini • Anna Occhipinti-Ambrogi \\ Consumption rates and prey preference of the invasive gastropod Rapana venosa in the Northern Adriatic Sea
}

Received: 24 April 2005/ Accepted: 21 November 2005/Published online: 1 February 2006

(C) Springer-Verlag and AWI 2006

\begin{abstract}
The alien Asian gastropod Rapana venosa (Valenciennes 1846) was first recorded in 1973 along the Italian coast of the Northern Adriatic Sea. Recently, this predator of bivalves has been spreading all around the world oceans, probably helped by ship traffic and aquaculture trade. A caging experiment in natural environment was performed during the summer of 2002 in Cesenatico (Emilia-Romagna, Italy) in order to estimate consumption rates and prey preference of $R$. venosa. The prey items chosen were the Mediterranean mussel Mytilus galloprovincialis (Lamarck 1819), the introduced carpet clam Tapes philippinarum (Adams and Reeve 1850), both supporting the local fisheries, and the Indo-Pacific invasive clam Anadara (Scapharca) inaequivalvis (Bruguière 1789). Results showed an average consumption of about 1 bivalve prey per day (or $1.2 \mathrm{~g}$ wet weight per day). Predation was species and size selective towards small specimens of $A$. inaequivalvis; consumption of the two commercial species was lower. These results might reduce the concern about the economical impact on the local bivalve fishery due to the presence of the predatory gastropod. On the other hand, selective predation might probably alter local community structure, influencing competition amongst filter feeder/suspension feeder bivalve species and causing long-term ecological impact. The large availability of food resource and the habitat characteristics of the Emilia-Romagna littoral makes this area an important breeding ground for $R$. venosa in the Mediterranean Sea, thus worthy of consideration in order to understand the bioinvasion ecology of this species and to control its likely further dispersal.
\end{abstract}

Communicated by K. Reise

D. Savini $(\bowtie) \cdot$ A. Occhipinti-Ambrogi

Ecology Section, Department of "Ecologia del Territorio",

University of Pavia, Via S. Epifanio 14, 27100 Pavia, Italy

E-mail: dario.savini@unipv.it

Tel.: + 39-382-984875

Fax: $+39-382-304610$
Keywords Rapana venosa $\cdot$ Gastropod · Introduced species $\cdot$ Predation $\cdot$ Northern Adriatic Sea

\section{Introduction}

The Asian whelk Rapana venosa (Valenciennes 1846) was unintentionally introduced along the Northern Adriatic littoral in the 1970s (Ghisotti 1974). This gastropod is a successful invader of marine coastal/brackish ecosystems, being tolerant to wide variations in temperature, salinity and oxygen concentration (Zolotarev 1996; Mann and Harding 2003). Moreover, throughout spring and summer this dioecious species produces a large number of planktonic veliger larvae which persist in the water column for a minimum of 14 to a maximum of 80 days prior settlement on the sea bottom (ICES 2004), thus granting high dispersal opportunity (Savini and Occhipinti Ambrogi 2004). Its native distribution includes the Sea of Japan, Yellow Sea, Bohai Sea and the East China Sea to Taiwan (Lai and Pan 1980; Tsi et al. 1983). The whelk has been spreading very fast in the last century when it colonised the Black Sea since 1947 (Drapkin 1953), the Adriatic Sea since 1973 (Ghisotti 1974), the Aegean Sea since 1990 (Koutsoubas and Voultsiadou-Koukoura 1991), the American Atlantic Sea/ Chesapeake Bay since 1998 (Harding and Mann 1999), and the South Atlantic/Bahia Samborombon, Uruguay and Argentina since 1999 (Pastorino et al. 2000). Few live specimens were reported also for the Tyrrhenian Sea (Terreni 1980; Paolini 1987) and the Northern Atlantic coasts of France/Quiberon Bay (Goulletquer 2000). Ballast water transport was claimed as the main vector of introduction for the species (ICES 2004), although trade of bivalve stocks and spat could represent an additional important dissemination route (Goulletquer 2002).

This large (up to $160 \mathrm{~mm}$ shell length) predatory gastropod is considered a pest; it has been causing the depletion of large stocks of commercial bivalves (oysters, mussels, and clams) in the Black Sea since the 1950s 
(Drapkin 1963; Ciuhcin 1984; Zolotarev 1996). So far, no similar threats to the ecosystem were reported in the other localities of introduction, but the international scientific community agrees in considering $R$. venosa a dangerous alien species for which study efforts should be prioritised (ICES 2004).

Since 2001, our research group is conducting baseline investigations in order to understand $R$. venosa distribution, population structure, and ecology in Italian waters. The aim of our study is the preparation of a risk assessment protocol for managing $R$. venosa bioinvasion, foreseeing further spreading, defining risk levels and thresholds of risk acceptability.

A very important step forward in defining the protocol is represented by understanding the complexity of biotic interactions, such as predation and competition, between the invasive gastropod and the benthic community; these interactions need to be quantified for a reliable evaluation of the ecological impact of the gastropod in the recipient ecosystem.

Investigations conducted by Harding and Mann (1999) in the Chesapeake Bay showed that R. venosa occupies an important position as a secondary consumer in the native food web of coastal ecosystem, preying on native filter feeders and suspension feeders bivalves. It was shown experimentally that, differing from other muricids, this gastropod preys only on live specimens avoiding carrions; an adult specimen of $140 \mathrm{~mm}$ length is capable of consuming an $80 \mathrm{~mm}$ shell length clam in less than $1 \mathrm{~h}$. Feeding experiments showed preferences for local hard clams (Mercenaria mercenaria) while other bivalves such as Crassostrea virginica, Mya arenaria and Mytilus edulis were eaten only when M. mercenaria were unavailable. Large $R$. venosa (101-160 mm shell length) were able to consume on average $1.5 \mathrm{~g}$ of $M$. mercenaria (wet weight) per day at a water temperature of approximately $26^{\circ} \mathrm{C}$ (Savini et al. 2002).

According to the optimal foraging theory (Hughes 1980), R. venosa could behave as a "pursuer" that searches for specific prey, thus maximizing its net rate of energy intake spending much time in handling a specific prey than searching for general prey species. The introduction of a new predator would cause complex structural changes in the community, directly influencing population density, distribution and growth of the preferred prey and indirectly modifying interspecific relationships amongst local prey species. It is largely recognised that when an alien species finds optimal conditions for its growth and reproduction (i.e. large availability of food and a suitable habitat for reproduction), the lack of an efficient control on it by competitors/predators could determine a collapse of the entire trophic web; well-known examples of such situations are the bioinvasion of the comb jelly Memniopsis leidyi in the Black Sea/Caspian Sea (Shiganova et al. 2001; Shiganova et al. 2003) or of the European green crab Carcinus maenas along the coasts of United States and Australia (Grosholz and Ruiz 1995; Walton et al. 2002).
In this paper, we present the results of an experimental investigation aiming at quantifying $R$. venosa consumption rates and prey preferences in Cesenatico (Emilia-Romagna, Italy), a locality in the Northern Adriatic Sea, where the gastropod has been showing a constant increase in population density (Savini et al. 2004; Savini and Occhipinti Ambrogi, unpublished data). Our hypotheses is that $R$. venosa could act as a pursuer also in our study area, where, due to the local abundance of different potential bivalve prey, food availability is not a limiting factor. This preliminary investigation on the dietary requirement of $R$. venosa would represent a starting point for understanding the potential ecological impact of this species in the Northern Adriatic Sea.

\section{Materials and methods}

\section{Study site}

The study was conducted along the littoral of Cesenatico (Emilia-Romagna, Italy) in the Northern Adriatic Sea (Fig. 1), a sandy bottom habitat where the only hard substrata are represented by man-made coastal projections such as piers, a tourist port and an almost continuous belt of limestone artificial reefs, $50-300 \mathrm{~m}$ from the coast, built in the 1970s for preventing beach erosion. Low depth, moderate tidal excursion, variable salinity/temperature ranges and eutrophication are important environmental characteristics of the study site (Montanari et al. 2003). The soft bottom macrobenthic community corresponds to the "Fine Sand biocoenosis in very shallow waters" described by Pérès and Picard (1964), dominated by the bivalves Lentidium mediterraneum, Chamelea gallina and the polychaetes Owenia fusiformis, Prionospio caspersi; other non-indigenous species are particularly abundant in the area such as the commercially exploited introduced clam Tapes philippinarum (Breber 2002), and the invasive Indo-Pacific clam Anadara inaequivalvis (Mizzan 1999).

The hard bottom community living on the artificial limestone reefs is characterised in larger proportion by the Mediterranean mussel Mytilus galloprovincialis, and in lower proportion by the flat oyster Ostrea edulis and the introduced Pacific oyster Crassostrea gigas (Savini and Occhipinti Ambrogi unpublished data).

\section{Experimental layout}

During May-July 2002, eight experimental plastic cages $\left(50 \times 50 \times 50 \mathrm{~cm}^{3}-1 \mathrm{~cm}\right.$ external, $0.3 \mathrm{~mm}$ internal mesh) were positioned under a pier $\left(\phi=44^{\circ} 13^{\prime} 1^{\prime \prime} \mathrm{N}\right.$; $\left.\lambda=12^{\circ} 23^{\prime} 5^{\prime \prime} \mathrm{E}\right)$ and fixed to the sea bottom at $1.5-2 \mathrm{~m}$ depth. Eight $R$. venosa specimens $(99-110 \mathrm{~mm}$ shell length - SL) were collected by scuba diving along the artificial reefs, kept in an additional cage positioned near the experimental site and starved for $48 \mathrm{~h}$ prior to the 
Fig. 1 Location of the experimental site in Cesenatico $\left(\phi=44^{\circ} 13^{\prime} 1^{\prime \prime} \mathrm{N} ; \lambda=12^{\circ}\right.$ 23'5'"E). The black arrow indicates the position of the experimental enclosures fixed under the pier in the picture

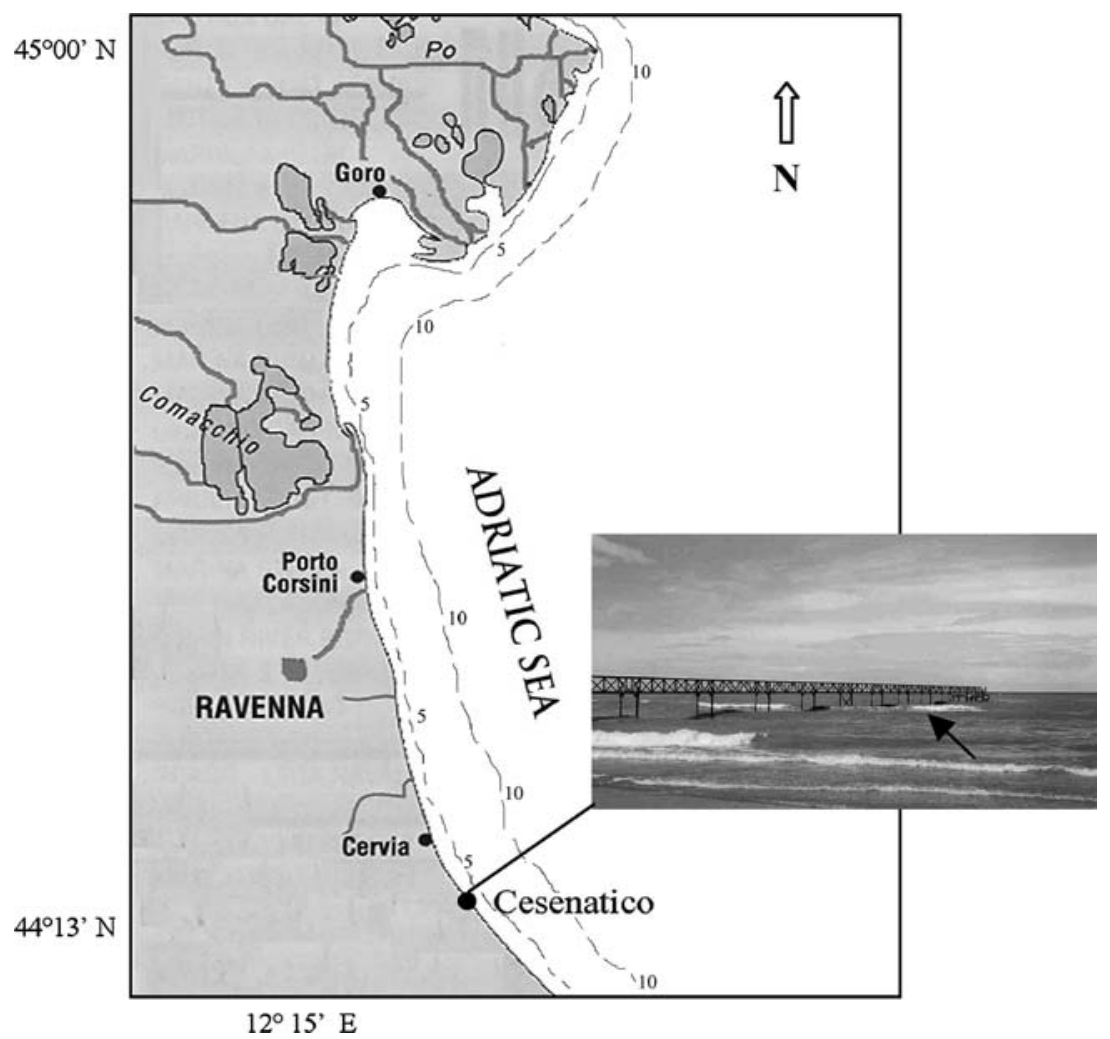

Prey biometry

start of the experiment in order to standardise hunger levels. Three species, all common representative of the local shallow water bivalve community, were selected as prey for the experiment: the commercially exploited Pacific carpet clam T. philippinarum, the Mediterranean mussel $M$. galloprovincialis and the invasive ark clam $A$. inaequivalvis; prey were collected from the area surrounding the experimental site by scuba diving and put into each experimental cage, divided in two length size classes ( $\mathrm{SC} 1 ; \mathrm{SC} 2)$ as follows:

1. T. philippinarum: 10 ind. $\mathrm{SC} 1=15-30 \mathrm{~mm} \mathrm{SL} ; 10$ ind. $\mathrm{SC} 2=31-45 \mathrm{~mm} \mathrm{SL}$

2. A. inaequivalvis: 10 ind. $\mathrm{SC} 1=15-30 \mathrm{~mm} \mathrm{SL} ; 10$ ind. $\mathrm{SC} 2=31-45 \mathrm{~mm} \mathrm{SL}$

3. M. galloprovincialis: 5 ind. $\mathrm{SC} 1=20-60 \mathrm{~mm} \mathrm{SL} ; 5$ ind. $\mathrm{SC} 2=61-90 \mathrm{~mm} \mathrm{SL}$

Bivalves were arranged so that $R$. venosa initially had the same probability of encountering each size of prey (i.e. the predator at the centre of the cage with bivalves of alternating species and size spaced evenly around it).

Starting from May 1st 2002, for an experimental period of 44 days, enclosures were examined two-three times a week by scuba diving, removing and measuring (calliper: $0.1 \mathrm{~mm}$ ) the empty shells of all prey eaten. In the same occasions, bivalves consumed were replaced with prey of similar dimensions thus maintaining constant prey/size availability. Water temperature (mercury thermometer) and salinity (portable refractometer) values were recorded in the experimental cages at each control.
A size range of 50 bivalve specimens for each prey species was collected by scuba diving both on sandy bottom (A. inaequivalvis: $17-57 \mathrm{~mm} \mathrm{SL}$; T. philippinarum: $22-37 \mathrm{~mm}$ SL) and rocky reefs (M. galloprovincialis: $20-65 \mathrm{~mm}$ SL). Samples were individually measured (shell length, $\mathrm{mm}$ ) and weighed prior the removal of the soft tissue; soft tissue was weighted (wet weight, g) to the nearest $0.1 \mathrm{~g}$. Data were utilised for elaborating prey size/weight relationships.

Prey density

Prey density at the study site was estimated by random quadrate sampling. $T$. philippinarum and $A$. inaequivalvis population densities were computed digging out and counting the number of bivalves collected in square frame (side: $50 \mathrm{~cm}$ ) randomly flung on the sea bottom at low tide per 35 spatial replicates. M. galloprovincialis density was assessed by scuba diving along the limestone reefs of Cesenatico, scraping a $15 \times 15$ surface (in 24 replicates) of the mussel community in a steel sampling net $(0.5 \mathrm{~mm}$ mesh).

\section{Data analysis}

Data analysis was performed utilizing the multivariate techniques described by Roa (1992) for multiple-choice 
feeding-preference experiments. An analogous of Quade's (1979) statistic test, the Friedman test (Conover 1999) was applied to the data set using the software StatsDirect Version 2.4.5. Linear regression analysis between linear and non-linear parameters (i.e. length/ weight relationships) were performed using the software Minitab 12.0 Student Edition; data were $\log _{10}$ transformed in order to normalise/homogenise variances; significance levels for all statistical tests were established at $P=0.05$ a priori.

\section{Results}

Prey preferences and consumption rates

A total of 280 bivalves (196 A. inaequivalvis, 48 T. philippinarum, $36 \mathrm{M}$. galloprovincialis) were consumed by eight Rapana individuals. Predation was discontinuous during the whole experimental period (Fig. 2).

A clear preference for A. inaequivalvis was observed; this species was consumed during the entire period, whereas T. philippinarum and were consumed mainly in the first and $M$. galloprovincialis in the last weeks of the experiment. The average consumption rate of $A$. inaequivalvis ( \pm standard deviation) per cage was $25 \pm 10$ ind.; T. philippinarum, $6 \pm 3$ ind.; M. galloprovincialis, $5 \pm 4$ ind. Friedman test confirmed significant differences between the number of individuals eaten of the three prey species $\left(T_{2}(F)=16.7, d f=2\right.$, $P<0.05)$; whereas $A$. inaequivalvis was consumed more than the other two prey species $(P<0.05)$, no significant differences in consumption rates between $T$. philippinarum and $M$. galloprovincialis $(P>0.05)$ were found.
Prey biomass and consumption rates

Significant (ANOVA, $P<0.05 ; R^{2}>90 \%$ ) linear relationships were found between $\log _{10}$ wet weight $(\mathrm{g})$ and $\log _{10}$ shell length $(\mathrm{mm})$ for the three bivalve prey species (Table 1); the equations were utilised to infer, from the number of prey consumed and their dimensions, biomass (grams of wet weight) consumed in each experimental cage. The average wet weight consumption rate ( \pm standard deviation) per cage was: A. inaequivalvis: $21.3 \pm 8.7 \mathrm{~g}$, T. philippinarum: $5.1 \pm 2.5$, M. galloprovincialis: $28.9 \pm 25.1$ g. Friedman test confirmed significant differences between the biomass consumed of the three prey species (i.e. grams wet weight consumed per species) $\left(T_{2}(F)=3.8, d f=2, P<0.05\right)$; while $T$. philippinarum was less consumed than the other two prey species $(P<0.05)$, no significant difference in biomass consumption was found between $M$. galloprovincialis and $A$. inaequivalvis $(P>0.05)$. Dividing the average biomass consumed during the experimental period by the duration of the experiment (44 days) we obtained mean values of daily feeding rates for each prey species.

A Rapana specimen of $104.5 \pm 9.9$ average shell length (wet weight $=70.8 \pm 24.3 \mathrm{~g}$ ) ate daily $\sim 0.5 \mathrm{~g}$ wwt. $\mathrm{d}^{-1}$ A. inaequivalvis, $\sim 0.1 \mathrm{~g} \mathrm{wwt.} \mathrm{d}^{-1} T$. philippinarum, $\sim$ $0.6 \mathrm{~g}$ wwt. $\mathrm{d}^{-1} M$. galloprovincialis; the total daily food requirement being $\sim 1.2 \mathrm{~g} \mathrm{wwt} . \mathrm{d}^{-1}$.

Prey size selection

Results showed a clear preference for smaller size (SC1: 15-30 mm SL) clams (A. inaequivalvis, T. philippinarum); Two-way ANOVA confirmed significant differences between the number of the two size classes $(\mathrm{SC} 1 ; \mathrm{SC} 2)$ of

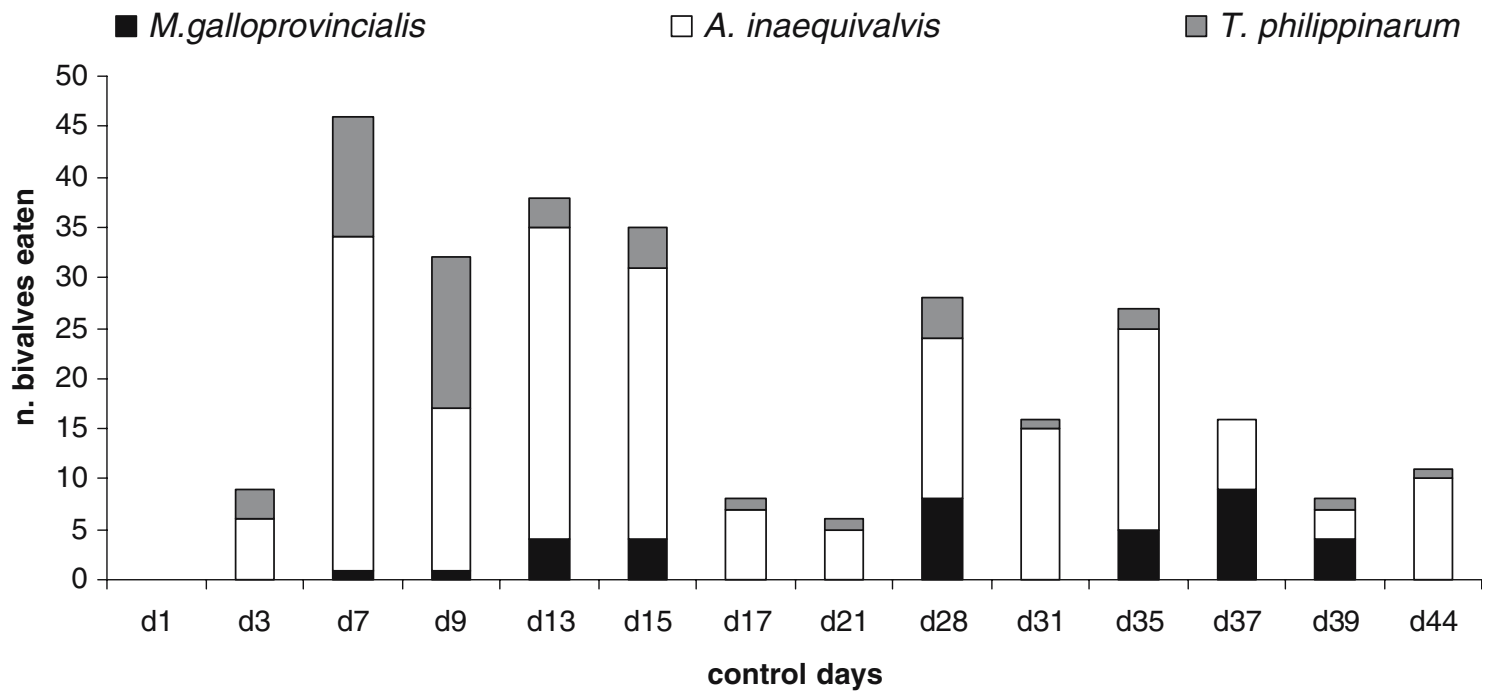

Fig. 2 Total number of bivalves eaten at each control day in the eight experimental cages 
Table $1 \log _{10}$ wet weight (wwt, g)/ $\log _{10}$ shell length (SL, mm) linear relationships for the three species of bivalve prey utilized in the feeding experiments

\begin{tabular}{llll}
\hline & A. inaequivalvis $(N .50)$ & $M$. galloprovincialis $(N .50)$ & $T$. philippinarum $(N .50)$ \\
\hline wwt $/ \mathrm{SL}$ & $\log \mathrm{wwt}=-4.29+3.10 \log \mathrm{SL}$ & $\log \mathrm{wwt}=-5.00+3.21 \log \mathrm{SL}$ & $\log \mathrm{wwt}=-4.47+3.20 \log \mathrm{SL}$ \\
ANOVA & $R^{2}=95.4 \% ; F=789.8 P<0.05$ & $R^{2}=97.3 \% ; F=1705.7 P<0.05$ & $R^{2}=97.1 \% ; F=1588.1 P<0.05$ \\
\hline
\end{tabular}

Significance of linear regressions has been tested by ANOVA: $R^{2}=$ regression coefficient; $F=$ ANOVA test; $P=95 \%$ confidence

prey eaten in all replicates (cages) (Table 2). As far as mussels (M. galloprovincialis) are concerned, the figure was less clear, due to the large variability of values amongst replicates (ANOVA showed significant differences between replicates).

\section{Discussion and conclusion}

In the Northern Adriatic Sea, $R$. venosa feeding rates were consistent with results of previous investigations in Chesapeake Bay (Savini et al. 2002); regardless prey species, the estimated average food requirement for an individual of $10-14 \mathrm{~cm}$ shell length was 1.2 (Northern Adriatic) to 1.5 (Chesapeake) g wwt. day ${ }^{-1}$.

Results of the experiment confirmed the hypothesis that $R$. venosa behaves as a "pursuer" also in the Northern Adriatic sea, where a clear preference for the invasive Indo-Pacific species $A$. inaequivalvis was shown. Moreover, a size selective predation towards small size prey was observed. Food preference could be explained by adopting a foraging behaviour which maximise the net rate of energy intake (Hughes 1980), i.e. choosing a prey which can be handled and consumed faster than other prey species. Although $R$. venosa presents the typical anatomical characters of a shell boring gastropod, such as the presence of an Accessory Boring Organ (ABO) (Carriker 1981), drilling behaviour has been observed only in the early life stage (Kingsley-Smith et al. 2003). Adult whelks hold their prey into the shell aperture rasping the shell margins or suffocating the bivalve, covering it with abundant mucus till it gasps (Savini et al. 2002). The prolapse of the valves might be facilitated by the presence of biotoxins in the mucus as

Table 2 Prey size selection. $N$. eaten total number of prey eaten. SC1 eaten number of small size class prey eaten. SC2 eaten number of large size class prey eaten.

\begin{tabular}{llll}
\hline Species & A. inaequivalvis & T. philippinarum & M. galloprovincialis \\
\hline N. eaten & 196 & 48 & 36 \\
SC1 eaten & 193 & 46 & 15 \\
SC2 eaten & 3 & 2 & 21 \\
ANOVA & & & \\
Size & $F=48.3 ;$ & $F=31.4 ;$ & $F=1.5 ;$ \\
& $P<0.05^{*}$ & $P<0.05$ & $P>0.05$ \\
Cage & $F=1.1 ;$ & $F=1.4 ;$ & $F=1.5 ;$ \\
& $P>0.05$ & $P>0.05$ & $P<0.05$ \\
\hline
\end{tabular}

Two-ways ANOVA results, with asterisk indicating significant differences amongst cages and prey dimensions (size) suggested by Cesari and Mizzan (1993) as the hypobranchial gland of different muricid and thaidid gastropods produces toxins (urocanilcoline, diihydromurexine, and senecioilcoline) impairing neuro-muscular transmission (Ghiretti and Cariello 1984). Biochemical tests on $R$. venosa mucus would be important to understand the gastropod foraging strategy and justify the observed preferences, as a higher sensibility of a prey species to toxins would minimise prey handling time, maximizing energy profit.

In the ecological context of the study area, high feeding rates on a non-indigenous bivalve species with no commercial interest, such as A. inaequivalvis, could have the positive effect of limiting the distribution of this alien bivalve along the Northern Adriatic coasts. On the other hand, a wide availability of this food resource helps maintenance and further spreading of its predator $R$. venosa. Anadara (Scapharca) inaequivalvis is present along the Adriatic shores since 1969 (Ghisotti 1972). In a few years, this species became dominant in the SFBC biocoenosis (sensu Pérès and Picard 1964) outcompeting the native bivalve Chamelea gallina and other native (e.g. Tapes decussatus, Cerastoderma glaucum) and non native (e.g. Tapes philippinarum) bivalves (Ghisotti and Rinaldi 1976; Taviani et al. 1985).

Density of $A$. inaequivalvis at the study site was estimated in about 600 ind $100 \mathrm{~m}^{-2}$ (the correspondent density of $R$. venosa being of 4 ind. $100 \mathrm{~m}^{-2}$ (Savini et al. 2004). If every month and a half (44 days experimental period) a gastropod eats on average 25 Anadara, the bivalve population would be reduced by $\sim 17 \%$ : Feeding rate $(25) \times$ Rapana density (4)/Anadara density (600) * $100=\%$ density reduction $(16.7 \%)$.

Complex synergistic interactions between introduced species and the recipient community usually occur, in some cases accelerating impacts on native ecosystems, the so-called invasional 'meltdown' process (Simberloff and Von Holle 1999); in the case of $R$. venosa introduction, selective predation on $A$. inaequivalvis might, at the contrary, weaken the competitive pressure of this alien on other local bivalve species. This could both support the re-colonisation of the habitat by native species, such as $C$. gallina, and help the diffusion of other well established non-indigenous species, such as T. philippinarum. These considerations are highly speculative but they could represent a basis for future experimental investigations, such as the evaluation in mesocosms (i.e. experimental ecosystems) of community structural changes and biodiversity alteration occurring in presence of the predatory gastropod; for the moment, 
there are not enough available information to foresee the effects of the removal of the competitive pressure of $A$. ineaquivalvis on the structural complexity of the infaunal community.

The lower consumption rates observed for $T$. philippinarum ( $6 \pm 3$ ind. in 44 days; average population density $=2,200 \pm 1,400$ ind. $100 \mathrm{~m}^{-2}$ ), which constitutes the most important bivalve fishery resource in the area, reduce the concern about the potential economical threat to bivalve fishery due to Rapana predation. Also, $M$. galloprovincialis (consumption rates: $5 \pm 4$ ind. in 44 days; average population density $=14,000 \pm 5,000$ ind. $100 \mathrm{~m}^{-2}$ ) do not seem in danger of depletion, especially because they are locally harvested on suspended ropes locally called "reste", which do not reach the sea bottom, thus preventing the predatory gastropod to reach them. Large natural mussel stocks are present on the artificial rocky reefs of Cesenatico and are consumed all year round by Rapana (author's personal observation), but this population is not commercially exploited, since collection is forbidden due to the risk of algal blooms and toxin infections (DSP, PSP) (Ade et al. 2003).

In summary, the experimental results obtained do not support the hypothesis of an economical threat posed by the gastropod in the study area, whereas a selective predation towards another non-indigenous species (A. inaequivalvis) might play an important role in regulating the local introduced population of the bivalve and altering the benthic community structure.

$R$. venosa has found optimal conditions for its development along the Northern Adriatic coast, and particularly in Emilia-Romagna, where an almost continuous belt $(\sim 31 \mathrm{~km})$ of rocky artificial reefs offers a large area for reproduction (Savini and Occhipinti Ambrogi 2004) and the surrounding sandy bottom provides a vast quantity of food resources. Taking the above into consideration, the area represents a breeding ground for $R$. venosa in the Mediterranean Sea, thus it is a relevant study place where further investigations aimed at the understanding of the bioinvasion ecology of this species should take place.

Acknowledgements We thank the Regional Agency for the Protection of the Environment (ARPA-Emilia-Romagna) and its Oceanographic Structure "Daphne" for the logistic support. We also thank Tino Zanoli, Mauro Favruzzo and Michela Castellazzi for field work assistance. The methods used in this experiment comply with the current laws in Italy. The authors acknowledge the support by the MARBEF Network of Excellence "Marine Biodiversity and Ecosystem Functioning" which is funded in the Community's Sixth Framework Programme (Contract no. GOCE-CT2003-505446). This publication is contribution number MPS060011 of MarBEF.

\section{References}

Ade P, Funari E, Poletti R (2003) Il rischio sanitario associato alle tossine di alghe marine. Ann Ist Super Sanità 39:53-68
Breber P (2002) Introduction and acclimatisation of the Pacific carpet clam, Tapes philippinarum, to Italian waters. In: Leppakoski E, Gollasch S, Olenin S (eds) Invasive aquatic species of Europe. Distribution, impacts and management. Kluwer, Dordrecht, pp 120-127

Carriker MR (1981) Shell penetration and feeding by naticacean and muricacean predatory gastropods: a synthesis. Malacologica 20:403-422

Cesari P, Mizzan L (1993) Osservazioni su Rapana venosa (Valenciennes, 1846) in cattività. Boll. Mus civ St nat Venezia 42:9-21

Ciuhcin VD (1984) Ecology of the gastropod molluscs of the Black Sea. Acad. Sc. USSR, Kiev Naukova Dumka

Conover WJ (1999) Practical Nonparametric Statistics. Wiley, New York

Drapkin E (1953) Novii molliusc v Cernom more. Priroda 8:92-95

Drapkin E (1963) Effect of Rapana bezoar Linné (Mollusca, Muricidae) on the Black Sea fauna. Doklady Akademii Nauk SRR 151:700-703

Ghiretti F, Gariello L (1984) Gli animali marini velenosi e le loro tossine. Piccin, Padova

Ghisotti F (1972) Ritrovamenti malacologici nel Mediterraneo. Conchiglie, Milano 8:21

Ghisotti F (1974) Rapana venosa (Valenciennes), nuova ospite Adriatica? Conchiglie, Milano 10:125-126

Ghisotti F, Rinaldi E (1976) Osservazioni sulla popolazione di Scapharca, insediatasi in questi ultimi anni su un tratto del litorale romagnolo. Conchiglie, Milano 12:183-195

Goulletquer P (2000) Report on the current status of introductions in France (Marine environment). Report of the Working Group on Introductions and Transfers of Marine Organisms, Parnu, Estonia, March 27-29, 2000. International Council for the Exploration of the Sea, Copenhagen, Denmark, pp. 24-27

Goulletquer P (2002) Report on the current status of introductions in France (Marine environment). Report of the Working Group on Introductions and Transfers of Marine Organisms, Gothenburg, Sweden, March 20-22, 2002. International Council for the Exploration of the Sea, Copenhagen, Denmark, pp. 31-33

Grosholz ED, Ruiz GM (1995) The spread and potential impact of the recently introduced European green crab, Carcinus maenas, in central California. Mar Biol 122:239-247

Harding JM, Mann R (1999) Observations on the biology of the veined Rapa Whelk, Rapana venosa, (Valenciennes, 1846) in the Chesapeake Bay. J Shellfish Res 18:9-17

Hughes RN (1980) Optimal Foraging Theory in the marine context. Ocean Mar Biol Ann Rev 18:423-481

ICES (2004) Alien Species Alert: Rapana venosa (veined welk). Mann R, Occhipinti A, Harding JM (eds) ICES Cooperative Research Report No. 264:14 pp

Kingsley-Smith PR, Mann R, Harding J (2003) A predation signature-based key to attribute predation upon bivalves to native versus invasive gastropods. Proceedings of the Third International Conference on Marine Bioinvasions, La Jolla, California, March 16-19, 2003, p 72

Koutsoubas D, Voultsiadou-Koukoura E (1991) The occurrence of Rapana venosa (Valenciennes, 1846) (Gastropoda, Thaididae) in the Aegean Sea. Boll. Malacologico, Milano 26:201-204

Lai KY, Pan CW (1980) The Rapana shells of Taiwan. Bull Malacol, Repub China 7:27-32

Mann R, Harding JM (2003) Salinity tolerance of larval Rapana venosa: implications for dispersal and establishment of an invading predatory gastropod on the North American Atlantic coast. Biol Bull 204:96-103

Mizzan L (1999) Le specie alloctone del macrozoobenthos della Laguna di Venezia: il punto della situazione. Boll Mus civ St nat Venezia 49:145-177

Montanari G, Rinaldi A, Ghetti A, Ferrari CR, Mazziotti C, Serra S (2003) Eutrofizzazione delle acque costiere dell'Emilia-Romagna. Rapporto annuale 2002. Agenzia Regionale Prevenzione e Ambiente dell'Emilia-Romagna, Centro Stampa della Giunta Regionale, 198 pp 
Paolini P (1987) Nuova segnalazione di Rapana venosa (Valenciennes, 1846) (Gastropoda, Muricidae) nell'alto Tirreno. Quad Mus Stor Nat Livorno 8:111-112

Pastorino G, Penchaszadeh PE, Schejter L, Bremec C (2000) Rapana venosa (Valenciennes, 1846) (Mollusca: Muricidae): a new Gastropod in South Atlantic Waters. J Shellfish Res 19:897-899

Pérès JM, Picard J (1964) Nouveau manuel de bionomie bentique de la Méditerranée. Rec Trav Stat Mar Endoume 31:5-137

Quade D (1979) Use of weighted rankings in the analysis of complete blocks with additive block effect. J Am Stat Assoc 74:680683

Roa R (1992) Design and analysis of multiple choice feedingpreference experiments. Oecologia 89:509-515

Savini D, Harding JM, Mann R (2002) Rapa whelk Rapana venosa (Valenciennes, 1846) predation rates on hard clams Mercenaria mercenaria (Linnaeus, 1758). J Shellfish Res 21(2):777-779

Savini D, Occhipinti Ambrogi A (2004) Spreading potential of an invader: Rapana venosa in the Northern Adriatic sea. Rapp Comm Int Mer Médit 37:548

Savini D, Castellazzi M, Favruzzo M, Occhipinti Ambrogi A (2004) The alien mollusc Rapana venosa (Valenciennes, 1846) (Gastropoda, Muricidae) in the Northern Adriatic Sea: population structure and shell morphology. Chem Ecol 20:411-424

Shiganova TA, Kamakin AM, Zhukova OP, Ushivtsev VB, Dulimov AB, Musaeva EI (2001) An invader of the Caspian Sea,
Comb Jelly Mnemiopsis, and the first consequences of its influence upon the pelagic ecosystem. Okeanologiya 41:542-549

Shiganova TA, Musaeva EI, Bulgakova YV, Mirzoyan ZA, Martynyuk ML (2003) Invaders ctenophores Mnemiopsis leidyi (A. Agassiz) and Beroe ovata Mayer 1912, and their influence on the pelagic ecosystem of Northeastern Black Sea. Biol Bull Russian Acad Sci 30(2):180-190

Simberloff D, Von Holle B (1999) Positive interactions of nonindigenous species: invasional meltdown? Biol Inv 1:21-32

Taviani M, Poluzzi A, Taviani N, Calamaras G (1985) Scapharca inaequivalvis: a recent invader of the Southern lagoons in the Po river delta plain. Rapp Comm int Mer Médit 29:179-181

Terreni G (1980) Molluschi poco conosciuti dell'Arcipelago Toscano: Gasteropodi. Boll Malacologico, Milano 16:9-17

Tsi CY, Ma XT, Lou ZK, Zhang FS (1983) Illustrations of the Fauna of China (Mollusca). Science Press, Beijing 2:1-150

Walton WC, MacKinnon C, Rodriguez LF, Proctor C, Ruiz G (2002) Effect of an invasive crab upon a marine fishery: green crab, Carcinus maenas, predation upon a venerid clam, Katelysia scalarina, in Tasmania (Australia). J Exp Mar Biol Ecol 272:171-189

Zolotarev V (1996) The Black Sea ecosystem changes related to the introduction of new mollusc species. PSZNI: Mar Ecology $17: 227-236$ 